\author{
Krystian Sowislok \\ II Liceum Ogólnokształcące \\ w Zabrzu
}

\title{
Wykorzystanie swobód wspólnego rynku Unii Europejskiej przez młodych Polaków
}

Rynek wewnętrzny Unii Europejskiej obejmuje obszar bez granic wewnętrznych, na terenie którego wprowadzono swobodny przepływ osób, towarów, usług i kapitału. Głównymi celami utworzenia wspólnego rynku były m.in. obniżenie cen produkcji towarów i obrotu nimi, zwiększenie dostępności i konkurencyjności usług oraz umożliwienie swobodnego przemieszania się w obrębie krajów Wspólnoty Europejskiej. Te działania miały przyczynić się do podniesienia poziomu życia obywateli państw członkowskich. Podstawę prawną do rozpoczęcia prac nad stworzeniem wspólnego rynku dało podpisanie 23 marca 1957 roku Traktatu rzymskiego o utworzeniu Europejskiej Wspólnoty Gospodarczej (EWG) przez sześć państw europejskich: Francję, Niemcy, Włochy, Belgię, Holandię i Luksemburg.

1. Swobodny przepływ osób - zgodnie z tą zasadą wszyscy obywatele Unii Europejskiej mają prawo do przemieszczania się bez konieczności posiadania wiz i zezwoleń, osiedlania się, a także, z pewnymi wyjątkami obejmującymi również obywateli polskich, podejmowania działalności gospodarczej i pracy w innym kraju Wspólnoty. Podejmując pracę lub inną działalność ekonomiczną w innym państwie UE, wszyscy muszą być traktowani przez to państwo w taki sam sposób, w jaki to państwo traktuje swoich obywateli, bez jakiejkolwiek dyskryminacji. Dotyczy to m.in. respektowania równych praw obywateli innych państw UE wynikających z ustalonych do tej zasad gwarancji. Odnoszą się one do:

- praw wyborczych,

- dostępu do rynku pracy,

- uznawania dyplomów i kwalifikacji zawodowych,

- koordynacji systemów zabezpieczenia społecznego.

Swoboda przemieszczania się i pobytu nie ma jednak charakteru absolutnego. W określonych przypadkach każde z państw członkowskich może nie zezwolić obywatelowi innego kraju UE na pobyt lub wydalić go z terytorium swojego kraju. Pobyt cudzoziemca w innym państwie członkowskim nie może być „ciężarem dla państwa przyjmującego”.

2. Swobodny przepływ towarów - oznacza, że na obszarze krajów Wspólnoty istnieje swoboda obrotu, tzn. eksportu i importu towarów. Najważniejszym etapem tworzenia wspólnego rynku było utworzenie unii celnej między państwami Wspólnoty, polegającej na zniesieniu barier celnych i ograniczeń ilościowych, stosowanych na granicach w stosunku do towarów zagranicznych oraz wprowadzeniu wspólnej taryfy celnej odnośnie towarów z państw spoza obszaru UE (tzw. państw trzecich). Nie są przeprowadzane kontrole graniczne, nie ma ograniczeń ilościowych i jakościowych w przepływie towarów. Towar, który został wprowadzony legalnie na teren któregoś z państw członkowskich, może być sprzedawany na terytorium każdego innego państwa UE. Ujednolicono także przepisy dotyczące importu towarów. 
3. Swobodny przepływ usług. Usługi obejmują działalność o charakterze przemysłowym i handlowym, działalność rzemieślniczą oraz wykonywanie wolnych zawodów. Są to świadczenia najczęściej odpłatne. Według klasyfikacji prawa wspólnotowego do obszaru usług nie są zaliczane usługi transportowe oraz usługi bankowe i ubezpieczeniowe, które związane są z przepływem kapitału. Próbę stworzenia wspólnego rynku usług, na którym usługi mogłyby być swobodnie dostarczane z jednego kraju do odbiorców w innych krajach, podjęto już w latach 80 . XX w. Swoboda ta daje możliwość zakładania przedsiębiorstw na terenie innego państwa członkowskiego, prowadzenia działalności gospodarczej na zasadach tzw. samozatrudnienia, wykonywania działalności poprzez założenie agencji, jak również tworzenie filii i oddziałów przedsiębiorstw mających swoją siedzibę w innym państwie UE. Obejmuje prawo jej prowadzenia zarówno w formach osobowych, jak i poprzez struktury natury korporacyjnej, np. spółki lub spółdzielnie. Podobnie jak w zasadzie dotyczącej swobodnego przepływu osób, państwa członkowskie obowiązuje zakaz stosowania jakichkolwiek środków ograniczających korzystanie ze swobody przepływu usług. W związku z tym przedsiębiorcy w krajach UE mogą być pewni, że zakładając firmę w innym niż swój kraju, nie będą gorzej traktowani niż ich lokalni konkurenci.

4. Swobodny przepływ kapitału. Zasada ta dotyczy samodzielnych transakcji finansowych, które nie są bezpośrednio związane z przemieszczaniem się ludzi, towarów czy usług. Oznacza możliwość transferu zysków z jednego kraju członkowskiego UE do drugiego, prawo inwestowania i nabywania wszelkich walorów rzeczowych i finansowych za granicą bez żadnych przeszkód. Obywatele UE maja prawo do dokonywania wszelkich operacji bankowych i finansowych we wszystkich państwach członkowskich, w tym prawo do posiadania konta osobistego w bankach, prawo zakupu i sprzedaży papierów wartościowych przedsiębiorstw całej UE.

Z tych swobód obecnie korzystają również obywatele polscy. Jako nauczyciela przedmiotu podstawy przedsiębiorczości interesuje mnie przede wszystkim przedsiębiorczość młodzieży, a w tym przypadku także, w jaki sposób młodzi ludzie wykorzystują szanse, które otworzyło przed nimi wstąpienie Polski do Unii Europejskiej.

\section{Metodologiczna strona badań}

Żeby poznać lepiej opinie młodych Polaków dotyczące rynku pracy i wykorzystania swobód, które omówione zostały wyżej, po raz kolejny przeprowadziłem wśród uczniów klas maturalnych szkoły, w której pracuję, badania. Zostały one poprzedzone dodatkowymi zajęciami, w trakcie których szczegółowo wyjaśnione zostały możliwości, jakie stwarzają przedstawione powyżej swobody. Wyniki tych badań porównałem z wynikami badań z 2006 roku.

Charakter badanych problemów, a więc postawy młodzieży na rynku pracy oraz plany dotyczące podjęcia pracy i dalszej edukacji po ukończeniu liceum, jest zmienny. Zależy od wielu czynników zewnętrznych. Można do nich zaliczyć przede wszystkim aktualną sytuację na rynku pracy w Polsce, liczbę i jakość przedsięwzięć podejmowanych w celu aktywizacji młodzieży i przygotowania jej do wejścia na rynek pracy oraz szanse podjęcia pracy i studiów za granica, jakie otworzyły się przed Polakami po wstąpieniu do Unii Europejskiej.

Badanie przeprowadzono metodą ilościową. Dzięki wynikom podobnych badań przeprowadzonych w 2006 roku możliwe było wykorzystanie metody porównawczej, którą stosuje się często w badaniach zjawisk życia społecznego w celu ustalenia cech i zachowań podobnych, identycznych lub odmiennych dla grup o zbliżonych charakterystykach. Jako technikę badawczą wykorzystano anonimową ankietę audytoryjną. Kwestionariusz ankiety zawierał zbiór dwunastu pytań, które dotyczyły doświadczeń zawodowych, wyobrażeń na temat zatrudnienia i pożądanych cech pracy oraz planów życiowych po maturze badanych uczniów. 
Wybór próby reprezentacyjnej opierał się na zasadach dowolnie przyjętych przez badającego. Jest to wybór celowy (dobór celowy to świadomy dobór obiektów do próby badanej ze względu na to, że spełniają one kryteria określonego rodzaju) (Sołoma 2002), w którym wykorzystano bezpośredni dostęp i posiadaną wiedzę o badanej zbiorowości.

Badania przeprowadzone zostały we wrześniu 2009 roku wśród uczniów klas trzecich II Liceum Ogólnokształcącego w Zabrzu, którzy są typowymi przedstawicielami polskiej młodzieży. Są, co bardzo istotne dla poznania badanych problemów, kolejnym rocznikiem kończącym naukę w liceum po wprowadzeniu przedmiotu podstawy przedsiębiorczości do programu szkół ponadgimnazjalnych. Ponadto w czasie swojej edukacji uczestniczyli w innych formach szkolenia i warsztatach związanych z rynkiem pracy. Ankietę wypełniło 106 uczniów.

\section{Wyniki ankiety}

Badania potwierdzają, że młodzież w Polsce jest coraz bardziej aktywna. Porównując wyniki (ryc. 1), widać (na podstawie opinii uczniów klas maturalnych II Liceum Ogólnokształcącego w Zabrzu), że rośnie liczba osób, które już w czasie nauki w szkołach ponadgimnazjalnych zdobywają pierwsze doświadczenia zawodowe. W roku 2006 było to $66 \%$, w $2009-72 \%$ uczniów. Młodzi ludzie poszukują zwykle pracy dorywczej, którą mogą wykonywać w weekendy lub sezonowej w czasie wakacji. Można powiedzieć, że rynek pracy im obecnie sprzyja. Wielu pracodawców, ze względu na panującą niepewność w gospodarce, preferuje pracę w niepełnym wymiarze godzin oraz formy zatrudnienia na podstawie umów czasowych. Młodzież doskonale wykorzystuje obecną sytuację, zbiera doświadczenia, które na pewno będą przydatne w przyszłości w poszukiwaniu i wykonywaniu pierwszej stałej pracy.

Ryc. 1. Podejmowanie pracy przez uczniów II LO w Zabrzu (w \%)
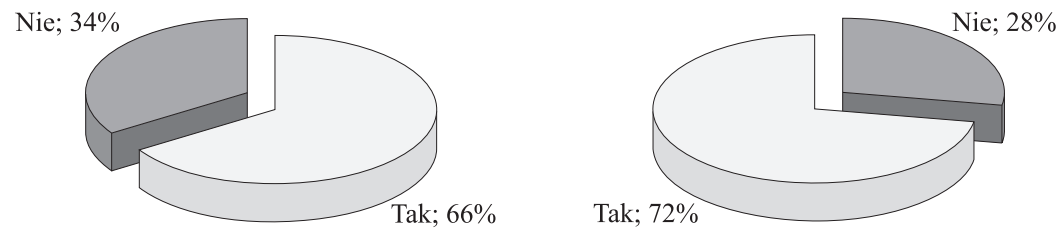

Źródło: opracowanie własne.

Zmiany na rynku pracy dotyczące zatrudniania mają także pewne minusy. Praca w niepełnym wymiarze godzin jest łatwiej dostępna, ale wielu pracodawców omija przepisy prawa pracy i zatrudnia młodych ludzi bez umowy - na czarno.

Po analizie wyników z roku 2006 i 2009 (ryc. 2), widać jednak poprawę w sposobie zatrudniania. W 2006 roku ponad połowa uczniów (53\%), którzy dotychczas pracowali, była zatrudniona bez umowy, wśród badanych w 2009 roku takich osób było o 20\% mniej (33\%). Znacznie zwiększyła się natomiast liczba zatrudnionych na podstawie umów o pracę (łącznie: umowa zlecenie, umowa o dzieło, inne umowy) - odpowiednio $28 \%$ i $55 \%$. 
Ryc. 2. Formy zatrudnienia badanych (w \%)
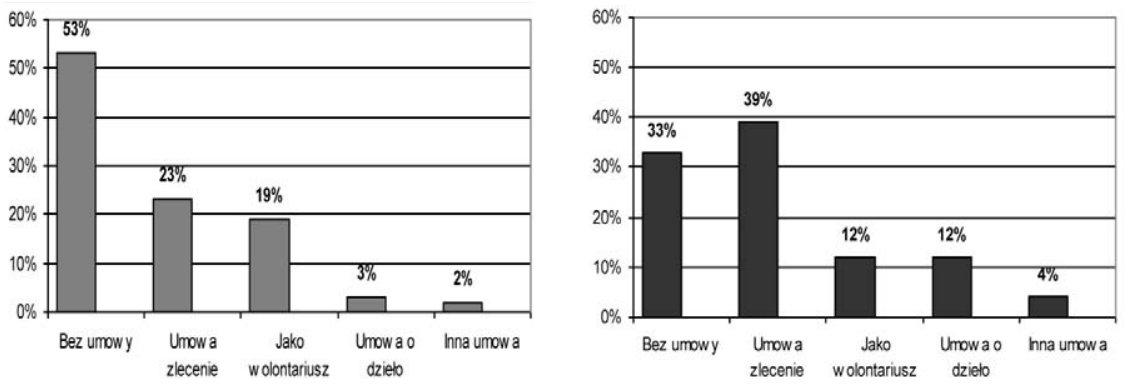

Źródło: opracowanie własne.

Młodzi ludzie zdają sobie sprawę, że aby podnieść swoją wartość na rynku pracy dla potencjalnych pracodawców, oprócz doświadczeń muszą zdobywać kolejne umiejętności i uprawnienia. Na pytanie Co należy robić, żeby zwiększyć swoje szanse na rynku pracy? uczniowie klas maturalnych II Liceum Ogólnokształcącego w Zabrzu najczęściej (można było zaznaczyć trzy odpowiedzi) wybierali naukę języków obcych. Podobną wagę przywiązywali do dalszego kształcenia. Na kolejnych miejscach znalazły się: uzyskiwanie dodatkowych uprawnień, licencji, uczestnictwo w kursach i szkoleniach oraz odbywanie praktyk za granica.

Ryc. 3. Czynniki zwiększające szanse młodych ludzi na rynku pracy według uczniów II LO w Zabrzu - zmiana w czasie 2006 i 2009 r.

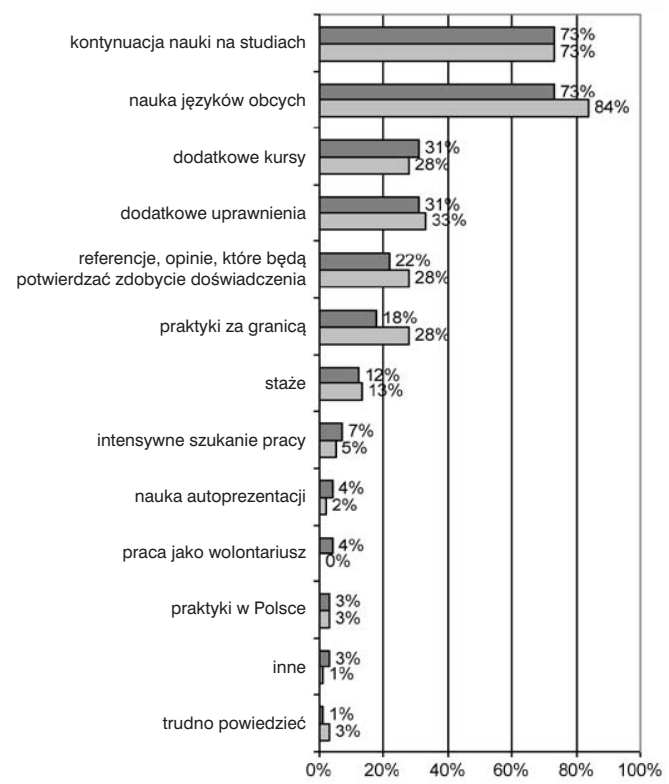

Źródło: opracowanie własne. 
Analizując wyniki ankiet, warto zwrócić również uwagę na tendencje wzrostowe i spadkowe w poszczególnych kategoriach. Wzrost: nauka języków obcych $-9 \%$, referencje, opinie $-6 \%$, praktyki za granica - 10\%. Spadki są nieznaczne w kategoriach rzadziej wybieranych przez uczniów: praca jako wolontariusz - 4\%, dodatkowe kursy - 3\%. Jak widać, w opiniach młodych ludzi rośnie z roku na rok znaczenie znajomości języków obcych, co związane jest między innymi z otwarciem unijnych rynków pracy dla Polaków, a także dokumentów potwierdzających zdobyte doświadczenie i praktyk zagranicznych. Ciekawa może się wydawać ta ostatnia kategoria. Problemem tym zajmowałem się już na konferencji w 2007 roku. Typowy pracodawca w Polsce nie jest zainteresowany partycypacją w kosztach praktycznej części edukacji młodego pokolenia. Nawet przyjęcie studenta na bezpłatną praktykę traktuje on jako obciążenie, bo uważa, że student - praktykant ,absorbuje niepotrzebnie” jednego z jego pracowników, który powinien efektywnie w tym czasie pracować. Sami pracodawcy nie kryją nawet tego, że tak właśnie myślą. Tylko około co czwarty pracodawca rozważa możliwość przyjęcia studenta na praktykę. Pozostali uważają, że praktykantom trzeba poświęcić zbyt dużo czasu i zainwestować w nich pieniądze (Blewąska, Pienias 2005). Wśród przeważającej części polskich pracodawców dominuje najczęściej postawa eksploatacji istniejącego potencjału pracowników, a nie inwestowania we własną kadrę. Za granicą praktykanta traktuje się jak każdego pracownika. Dzięki takiemu podejściu obie strony odnoszą korzyści. Praktykant nabywa konkretne praktyczne umiejętności, a jeżeli się sprawdzi, może liczyć w przyszłości na zatrudnienie w firmie, w której odbywa praktyki.

Wizerunek idealnej pracy na podstawie odpowiedzi uczniów jest jasny i konkretny, i raczej nie odbiega od opinii innych grup wiekowych. Praca powinna być przede wszystkim dobrze płatna. Poza tym istotne jest, aby dawała możliwość dalszego rozwoju, była interesująca i zgodna z wybranym zawodem. Mimo młodego wieku ankietowanych duże znaczenie ma dla nich również stałość zatrudnienia. Może to wynikać z faktu, że do tej pory, podejmując pracę, spotykali się oni z łamaniem praw pracowniczych, np. brakiem umowy o pracę, opóźnieniami w wypłacaniu lub obniżaniem wynagrodzenia oraz złym traktowaniem przez przełożonych.

Ryc. 4. Cechy dobrej pracy według uczniów II LO w Zabrzu - zmiana w czasie 2006 i 2009 r.

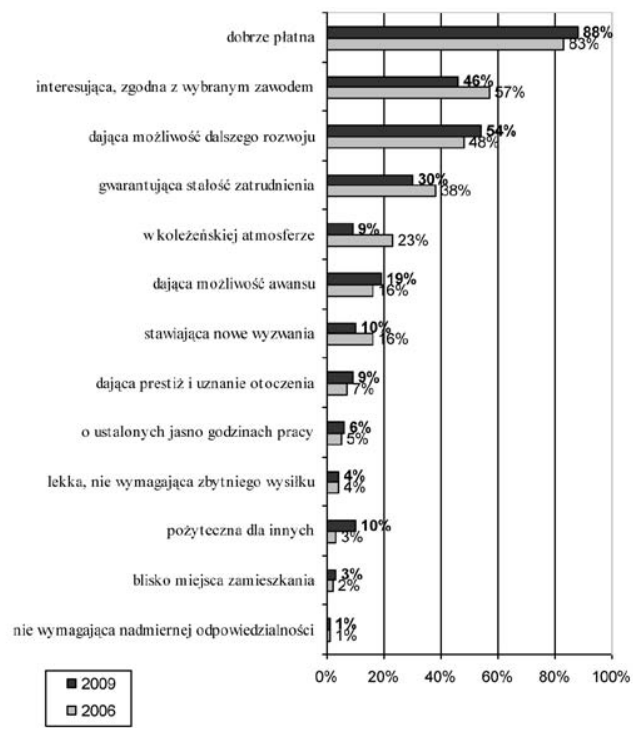

Źródło: opracowanie własne. 
Po porównaniu wyników z 2006 i 2009 roku widać, że największe zmiany dotyczą następujących cech: wzrost: pożyteczna dla innych $-7 \%$, dająca możliwość dalszego rozwoju - 6\%; spadek: interesująca i zgodna z wybranym zawodem - 11\%, gwarantująca stałość zatrudnienia $-8 \%$.

Ankietowani, uczniowie klas maturalnych, planują dalszą edukację. Obecnie ich wartość na rynku pracy jest bardzo niska, ponieważ są traktowani jak pracownicy niewykwalifikowani, bez zawodu. Wielu z nich myśli również o łączeniu nauki z pracą.

Ryc. 5. Plany uczniów II LO w Zabrzu dotyczące łączenia po maturze dalszej edukacji z pracą (w \%)

2006

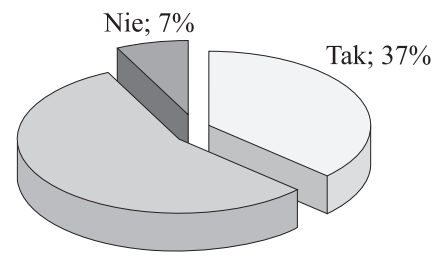

Dorywczo; $56 \%$
2009

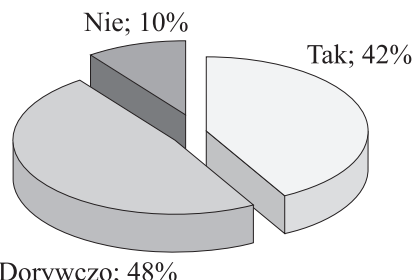

Dorywczo; $48 \%$

Źródło: opracowanie własne.

Porównując wyniki ankiet, można zaobserwować pewne zmiany dotyczące podejmowania pracy stałej: w 2006 roku - 37\%, w 2009 - 42\%; dorywczej: odpowiednio 56\% i 48\%. Niewielu spośród ankietowanych wykluczyło możliwość podjęcia pracy w trakcie studiów: odpowiednio $7 \%$ i $10 \%$.

Rycina 6 przedstawia skalę zjawiska dotyczącego planowanych wyjazdów uczniów do pracy za granicę. Zaznaczyć tu należy, że po raz pierwszy zadano ankietowanym to pytanie. W 2006 roku ponad połowa maturzystów (54\%) deklarowała chęć wyjazdu, przynajmniej wakacyjnego, za granicę do pracy, w 2009 roku takich osób było już tylko 37\%.

Ryc. 6. Plany uczniów II LO w Zabrzu dotyczące wyjazdu do pracy za granicę (w \%)

2006

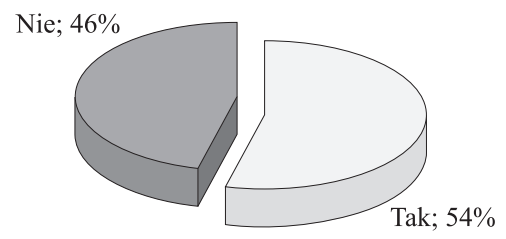

2009

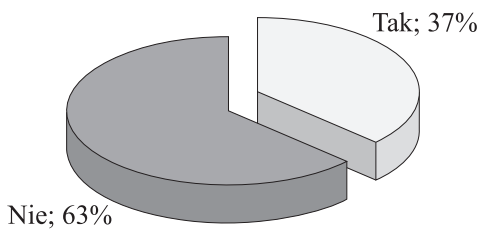

Źródło: opracowanie własne.

Teraz krótki komentarz dotyczący wyraźnego spadku zainteresowania emigracją zarobkową młodych Polaków. Taka tendencja jest związana z panującym na świecie kryzysem i związaną z tym większą trudnością uzyskania zatrudnienia, również w krajach do których wyjeżdżała dotychczas większość Polaków w poszukiwaniu pracy. Wydaje się jednak, że nawet tegoroczne zainteresowanie wyjazdem do pracy za granicę nie jest małe. Poza tym ważne jest, w jakim stopniu to zainteresowanie zmieni się w praktyczne decyzje dotyczące wyjazdu z Polski. Można w tym miejscu dodać, że w trakcie rozmów niektórzy uczniowie nie ukrywali, że jeżeli im się powiedzie, zostaną za granicą dłużej i są skłonni nawet przesunąć na później plany o podjęciu studiów. Zresztą część z nich, w sprzyjających okolicznościach, byłaby skłonna 
skorzystać z kolejnych praw wynikających z naszego członkowstwa w UE i zdecydować się na studia za granicą. Taką ewentualność bierze pod uwagę $22 \%$ ankietowanych (pytanie o plany dotyczące podjęcia studiów za granicą - ryc. 7 - umieściłem w ankietach po raz pierwszy).

Ryc. 7. Plany uczniów II LO w Zabrzu dotyczące podjęcia studiów za granicą - 2009 r. (w \%)

Nie; $78 \%$

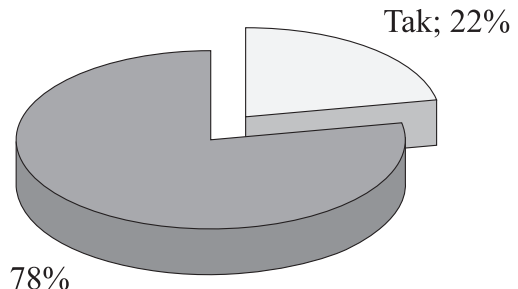

Źródło: opracowanie własne.

\section{Podsumowanie}

Przeglądając treść tego referatu, może nasunąć się czytelnikowi pytanie, dlaczego przeprowadzone badania dotyczyły w większości rynku pracy w Polsce, mimo że tytuł sugeruje „wspólny rynek UE”. Otóż w trakcie kolejnych konferencji wielokrotnie poruszany był problem przedsiębiorczości młodych ludzi oraz cech i postaw przedsiębiorczych, dla których charakterystyczne jest wykorzystanie szans pojawiających się w otoczeniu. Jeżeli wyobrażenia i oczekiwania młodych Polaków dotyczące przyszłej pracy, o których właśnie można tutaj przeczytać, nie mogą być zrealizowane w naszym kraju, istnieje dla ich realizacji jeszcze inna możliwość.

Korzystając ze swobód wspólnego rynku, młodzi ludzie mogą skonfrontować warunki życia i pracy w Polsce i za granicą. Niejednokrotnie mówi się, że w ten sposób tracimy dobrze wykształconych, czasem najzdolniejszych młodych ludzi. Sami jednak uczymy ich przedsiębiorczości i czy w związku z tym możemy mieć im to za złe?

\section{Literatura}

1. Blewąska J., Pienias M., 2005, Praktyki nie dla studentów, „Gazeta Wyborcza”, 13.06.2005.

2. Dyrektywa Rady 68/360/EWG w sprawie zniesienia ograniczeń w przemieszczaniu się i pobycie pracowników Państw Członkowskich i ich rodzin we Wspólnocie, 1968.

3. Dyrektywa Rady 73/148/EWG w sprawie zniesienia ograniczeń w zakresie przemieszczania się i pobytu obywateli Państw Członkowskich wewnatrz Wspólnoty, które dotycza przedsiębiorczości i świadczenia ustug, 1973.

4. Rola przedsiębiorczości w aktywizacji gospodarczej, seria „Przedsiębiorczość - Edukacja”, nr 3, 2007, Zioło Z., Rachwał T. (red.), Zakład Przedsiębiorczości i Gospodarki Przestrzennej Instytutu Geografii AP w Krakowie, wydawnictwo Nowa Era, Warszawa-Kraków.

5. Sołoma L., 2002, Metody i techniki badań socjologicznych, Wyższa Szkoła Pedagogiczna, Olsztyn.

6. Traktat ustanawiajacy Wspólnotę Europejskq, 1957.

7. www.ukie.gov.pl 


\section{Utilization of the European Union Common Market Freedoms by the Young Poles}

The internal market of the EU comprises an area with no internal borders, in which a free flow of persons, goods, services and capital has been introduced. Among the main aims of creating the common market were: lowering of prices and their turnover, an increase in availability and competitiveness of services and making unrestricted movement within the union possible. This was aimed to enhance living standards among citizens of member states.

Polish citizens are now enjoying these freedoms. As a teacher of entrepreneurship, I am interested mainly in entrepreneurship among young people, and in this particular case, in the way they are taking advantage of the opportunities created by Poland's accession to the EU. In order to become better acquainted with the opinions of young Poles' on the above mentioned topics, a survey was conducted among my secondary school students. As a result, I learned about the plans of secondary school final year students concerning further education or the search for employment, including the possibility of finding work abroad. Similar research was conducted in 2006 and 2007, presenting the opportunity to compare the results. The most important conclusions resulting from the comparison are the following: the students are closely following the economic situation of Poland and the EU, and are adapting their plans according to the changes currently taking place. 